\title{
Nursing Students Experience in Emergency and Intensive Care in a Reference Hospital
}

\begin{abstract}
Karen Rayara Bezerra Lima1, Tiago Alves de Brito1, Helena Marta Alves Nunes, Glória Catarina Beserra Rodriguez ${ }^{1}$, Rayane Araújo do Nascimento', Lívia Maria Nunes Henriques ${ }^{1}$, Kezauyn Miranda Aiquoc ${ }^{1}$, Ellen de Fátima Lima Vasconcelos ${ }^{1}$, José Joandson de Souza dos Santos ${ }^{1}$,
\end{abstract} Sabrina Daiane Gurgel Sarmento', Rodrigo Assis Neves Dantas², Daniele Vieira Dantas², Maria Alzete de Lima², Katia Regina Barros Ribeiro ${ }^{2}$, Janmilli da Costa Dantas ${ }^{3}$, Tatiana Melo dos Santos ${ }^{4}$, Maria Marinah Souza do Nascimento ${ }^{5}$, Isabelle Cristina Braga Coutinho Cunha6 ${ }^{6}$, Dayse Medeiros Bezerra ${ }^{7}$

\section{Abstract}

Objective: To report the experiences and activities carried out by nursing students during practical activities in the Intensive Care Unit and Emergency Room at a referral hospital.

Methods and results: This is an experience report of students from the nursing graduation course during the practical activities of the subjects Integral Attention to Health II, High Complexity module in Emergency and Intensive Care Unit of a reference state hospital in Natal, Rio Grande do Norte, in the period from 18 November to 08 October 2015. The experience provided the students a dimension of the nursing care in the high complexity services. Thus, the results have been described considering the procedures and knowledge used and the concept of this experience to the students in the hospitals.

Conclusion: During the development of the training activities, it is observed an important learning both individually and in groups of students. The progress in achieving the nursing care, the application
1 Nursing Student at the Federal University of Rio Grande do Norte (UFRN).

2 Ph.D. in Nursing. Associate Professor of the Department of Nursing of the Federal University of Rio Grande do Norte (UFRN).

3 Master in Nursing. Assistant Professor of the Department of Nursing at the Faculty of Health Sciences of Trairi/ UFRN.

4 Nurse graduated from UNIFACEX.

5 Nursing Student at the UNIFACEX.

6 Professor and Graduate Coordinator Health Area Estácio Ponta Negra/ Mauricio de Nassau.

7 Nursing graduated from Federal University of Paraíba (UFPB).

Contact information:

Karen Rayara Bezerra Lima.

झ karen_rayara@hotmail.com 
of the clinical reasoning associated with the referenced theoretical basis are increasingly set in carrying out the practice.

\section{Keywords}

Nursing Students; Critical Care Nursing; Intensive Care Units; Emergency

Medical Services

\section{Introduction}

Training activities in the nursing course are of great importance for the formation of the student. These activities must be carried out throughout the course by the student to consolidate the established abilities, allowing the knowledge, skills, and attitudes for the actions [1].

According to research [2], the internship is where the professional identity of the student is generated, built and described. It aims to the development of an experienced, reflective and critical action and, therefore, it should be planned gradually and systematically.

The nursing graduation of the Federal University of Rio Grande do Norte (UFRN) provides internship opportunities for the students, from basic care to high complexity in referral hospitals in the state of Rio Grande do Norte (RN).

Aiming at the quality of education, the mission of the Nursing course at the Federal University of Rio Grande do Norte - UFRN is to provide training to ensure the nurses expertise, ethics, and politics to work in the work process in Nursing, in all levels of comprehensive health care, with resoluteness, quality, and humanity. According to the Political Pedagogical Project of the course, the Supervised Training is seen as an activity performed in the first year of the course, following the levels of complexity of knowledge and skills developed by the student during the course under the direct supervision of the teacher. The student gets professional experience in real situations of life and works in the community, the basic health care and the outpatient and hospital area [3].

In the subject of Comprehensive Care II, High Complexity module taught in the sixth period of the course, the students learn about nursing care focused on medium and high complexity, with procedures and behaviors taught to watch the critical patient, mainly used in Emergency Care Units (ECU), Emergency Room (ER) and Intensive Care Units (ICU). Given the increased complexity of the issues, it is extremely necessary to practice in these areas.

The implementation of the Nursing Process (NP) requires skills and cognitive, psychomotor and affective abilities, which help to determine the observed phenomenon and its significance [4] to achieve quality in the care given, improved communication between the multidisciplinary team, and assist the needs of each patient with priority, being an extremely important factor in the high complexity services, because it is care of critical patients and critics.

The internships of high complexity give a new vision of assistance to the students with more complex procedures and a need for further theoretical and practical basis on the issues. Presenting the experiences, this article shows an experience of students during practical activities in ICU and ER of a public hospital, a reference in emergency rooms in the state of Rio Grande do Norte [5].

This article aims to report the academic experiences of nursing during the practical activities in 
the Intensive Care Unit and Emergency Room at a referral hospital to share the experiences of the students of the subject.

\section{Methods}

This is an experience report by scholars of the sixth period of the undergraduate degree in Nursing during the practical activities of the Comprehensive Health Care II, in the High Complexity module in the Emergency Room and Intensive Care Unit of a State referral hospital of the city of Natal/RN.

The experience reported a text whose social function is to report a lived experience. It is made of contextualized manner, with objectivity and theoretical contribution, bringing significant considerations on the experience [6].

The practical activities were supervised by teachers responsible for training and accompanied by the sector nursing team. As a pocket material notepad, pen, tensiometer, thermometer and stethoscope were used, as well as supplies and equipment from the hospital.

The internships occurred in the period from $18 \mathrm{No}-$ vember to 8 October 2015 and included: analyzing the medical records; physical exam; guidance on care to critically ill patients and some procedures such as nasogastric probing, enteral and bladder, dressings, blood gas analysis, cultures, among others.

\section{Results}

The objective of the subject of Comprehensive Health Care II, in the High Complexity module was to stimulate the clinical reasoning to promote care systematized to critically ill patients and a critical, reflective, creative and ethical, developing skills in nursing care in the Intensive Care Unit and in urgent and emergency situations in the Emergency Room and emergency care units [3].

From this perspective, the subject becomes very important for nursing students, since they need to know to deal with unexpected situations and acquire the skills necessary to provide us the best possible patient care in urgent, emergency and intensive care.

At the first internship, there was the presentation of the hospital's physical structure by the teacher, which established the purpose and functionality of each sector, as well as the contact with the human resources.

The internship in Emergency and ICU did not provide us use acquired knowledge not only on the subject of high complexity, as well as knowledge of previous courses.

There was an opportunity to broaden the experience in various procedures, such as injections with short-term catheter, nasogastric and nasogastric catheters, indwelling catheter and relief dressings for central access, continuous infusion pump handling and multiparameter monitor; but also some new knowledge put into practice, such as collecting blood gas analysis, water balance and participation in endotracheal intubation and Cardiopulmonary Resuscitation.

Both in the ICU and in the ER, the students had the chance to handle the mechanical ventilator, high-tech equipment used in patients with respiratory failure [5]; and also the trolley stop, considering their physical organization, drugs, equipment and equipment in them.

During the activities, the resources available were used, many times limited by being a more cautious and complex care. Also, the practice of emotional self-control was experienced. Also, the students were in direct contact and working multidisciplinary with other health professionals such as physiotherapists, nutritionists, dentists, doctors and nursing staff, obtaining higher learning, and conceptualizing the idea of a multi-professional team. For a teamwork existing, beyond the team spirit they must have mutual respect among professionals to play their role in their area of expertise effectively, combining knowledge, experience, and skills. 
The formation of a multidisciplinary team should be based on the patient's needs, based on the unit's objectives [7].

\section{Discussion}

The work in the ICU and ER is complex and intense. The nurse should be prepared and watchful for any time to exercise, seeing patients in emergencies, which require specific knowledge and ability to make decisions promptly [8]. They can unite all the knowledge learned and used them in a proper and expeditious manner, the ER and the ICU, allowed a broader view of the Nurse that is expected to end graduation.

Regarding the nursing work process, this experience provided an opportunity to see the role of the nurse when being a manager of a hospital sector and its importance for maintaining the flow of quality of services provided. For a consistent work planning with the characteristics of these units, nurses must consider not only the profile of the patients treated but also other essential elements for the care taking place such as human resources, necessary and available materials and equipment [9].

The ICU is characterized as a closed, and complex unit, with continuous monitoring that hospitalizes patients in hemodynamic instability. It provides support and intensive care, as well as specific equipment and other technologies for the diagnosis and treatment of the patient [10].

The routine of the emergency room is diverse, unlike the ICU that is already based on the predetermined service actions. Also, the turnover of the sector is also different. While in the ICU there are patients hospitalized for some time, in the SP, the patients are admitted, treated and then sent to another specialist sector. The Emergency Nurses are key to the routine sector work, not only for doing emergency care but also effectively acting on the unit's management, organizing the environment to meet the needs of each patient [11] better.
Over the internships, it is possible to observe that in addition to ability to carry out the procedures and emotional stability to deal with the routine of emergency units, it is necessary also have a broad theoretical basis to perform the function, because the use of vasoactive drugs that usually have a rapid and powerful action, they have a low therapeutic index that should be administered by the hemodynamic and laboratory monitoring [12], apart from the pathophysiology of the patient and even requiring detailed knowledge of the professional equipment.

The nurses who work in emergency units not only work in patients care but also with their treatment, coordinating and leading the nursing staff, and also acting in bureaucratic functions [13]. The systematization and organization of nursing work and the team are of great importance to qualify the assistance, especially when considering all the high complexity, becoming essential the practice of quality efficiency and effectiveness [14].

Emergency units are an important nursing workspace. It was found that the nurse is responsible for performing nursing prescriptions, records and procedures, specific from their category, which is part of the management, administration, organization, and control of the unit [15]. The importance of quality records for effective communication between the team was observed, which is a potentiating factor in the health status of the patients' improvement and quality in care.

\section{Conclusions}

The training activities enabled the acquisition of experience of working as a nurse in the emergency units, promoting improved performance as students. Despite the short period, the internships were improving in the academic area.

During the development of training activities, it was observed an important learning in the students both individually and in groups. The progress 
in achieving the nursing care, application of clinical reasoning associated with the referenced theoretical basis are increasingly in carrying out the practice.

An important point highlighted is the idea of the student being responsibility they have in the patients under their care in the days of the development of practical activities, concerning with the welfare of all, treating them with respect and dignity. The knowledge shared between teachers and students in the internship contributed positively to the teaching-learning process since it facilitated the exchange of experiences and allowed the inclusion in the current context of vocational training in the area. Furthermore, the internship is also a moment of entering the student in the health reality where many times he is impaired due to lack of professionals, the structure, and materials.

Finally, it is emphasized that there are still barriers to be broken in the internship of practical activities. It is believed that the practice time could be larger, allowing more activities and experience in the context of urgency, emergency, and intensive care.

\section{References}

1. Moura LC, Miranda MC, Moura LC, Souza SG. Estágio curricular supervisionado II: relato de experiência na estratégia saúde da família (ESF). [resumo]. Teresina: Faculdade Santo Agostinho, Curso de Enfermagem; 2010

2. Buriolla MAF. O estágio supervisionado. 6. Ed. São Paulo: Cortez, 2009.

3. Universidade Federal do Rio Grande do Norte. Projeto pedagógico do curso de graduação em enfermagem da UFRN/ Natal. Natal: Departamento de Enfermagem, UFRN, 2008, 57p.

4. Garcia TR, Nóbrega MML. Sistematização da assistência de enfermagem: há acordo sobre o conceito? Rev. Eletr. Enf. [Internet]. 2009; 11(2):233. Available from: http://www.fen.ufg. br/revista/v11/n2/v11n2a01.htm.

5. Câmara AG, Silva AKM, Souza AAM, et al. Vivência de acadêmicos de enfermagem em unidade de terapia intensiva: um relato de experiência. Rev. enferm. UFPE on line. 2012 Oct; $6(10): 2582-5$

6. Eulálio MM, Nascimento CJR, Albuquerque MSP. Didatizando o gênero relato de experiência no ensino fundamental - reflexão sobre reescrita textual. Revista Letras Raras ISSN: 2317-2347 Vol 2, N² 2013.
7. Kamada C. Equipe multiprofissional em unidade de terapia intensiva. Rev. Bras. Enferm. [Internet]. 1978 [cited 2016 July 18]; 31(1): 60-67.

8. Nogueira GM. Vivenciar o cotidiano de uma Unidade de Terapia Intensiva, um relato de experiência. [trabalho de conclusão de curso]. Ijuí: Universidade Regional do Noroeste do Estado do Rio Grande do Sul, Curso de Enfermagem, Departamento de Ciências da Vida; 2012.

9. Chaves LDP; Laus AM; Camelo SH. Ações gerenciais e assistenciais do enfermeiro em unidade de terapia intensiva. Revista Eletrônica de Enfermagem, Goiânia, v. 14, n. 3, p. 6718, set. 2012. ISSN 1518-1944. [cited 201619 Jul] Available from: http://www.revistas.ufg.br/fen/article/view/15724.

10. Fernandes HS, Silva E, Capone Neto A e col. Gestão em terapia intensiva: conceitos e inovações. Rev. Soc. Bras. Clín. Méd. São Paulo, 2011 Mar-Apr; 9(2):129-37

11. Montezeli JH. O trabalho do enfermeiro no pronto-socorro: uma análise na perspectiva das competências gerenciais. 2009. 135 f. Dissertação (Mestrado) - Universidade Federal do Paraná, Curitiba. 2009.

12. Ostini FM et al. The use of vasoactives drugs in the intensive care unit. Medicina, Ribeirão Preto, 31: 400-411, july/sept. 1998.

13. Wehbe G; Galvão C M. O enfermeiro de unidade de emergência de hospital privado: algumas considerações. Rev. Latino-Am. Enfermagem, Ribeirão Preto, v. 9, n. 2, Apr. 2001.

14. Truppel TC, Meier MJ, Calixto RC, Peruzzo SA, Crozeta K. Sistematização da Assistência de Enfermagem em Unidade de Terapia Intensiva. Rev. bras. enferm. [Internet]. 2009 Apr [cited 2016 July 19]; 62(2): 221-227.

15. Pirolo SM, Ferraz CA, Gomes R. A integralidade do cuidado e ação comunicativa na prática interprofissional da terapia intensiva. Rev. Esc. Enferm. USP. 2011; 45 (6): 1396-1402.
Publish in International Archives of Medicine

International Archives of Medicine is an open access journal publishing articles encompassing all aspects of medical science and clinical practice. IAM is considered a megajournal with independent sections on all areas of medicine. IAM is a really international journal with authors and board members from all around the world. The journal is widely indexed and classified Q2 in category Medicine. 